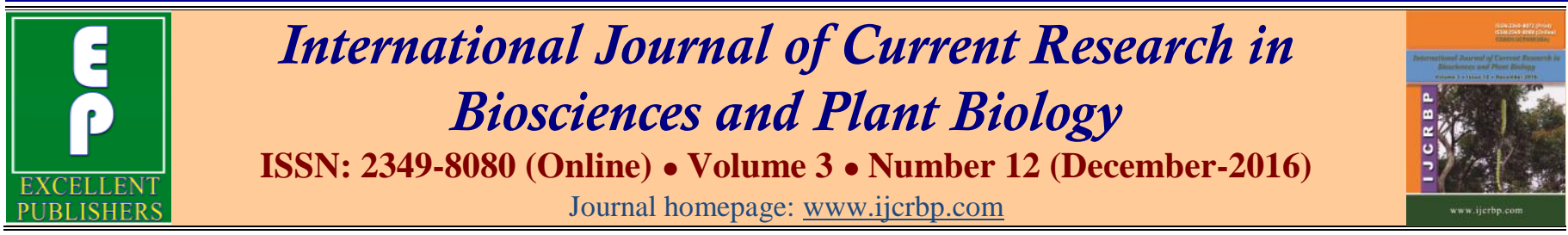

\title{
Effect of Temperature and Duration of Storage on Some Qualitative Characteristics of Two Local Varieties of Pear Fruits (Pyrus communis)
}

\author{
Ayman Ismail Ahmed ${ }^{1 *}$, Jasim Mohamad Khalaf ${ }^{2}$ and Sardar Saeed Amin ${ }^{3}$
}

${ }^{1}$ College of Agriculture, University of Kirkuk, Haweja, Iraq

${ }^{2}$ College of Agriculture, University of Kirkuk, Haweja, Iraq

3 Faculty of Agricultural Sciences, University of Sulaimani, Iraq

*Corresponding author.

\begin{abstract}
This study includes storage operation for two local Pear varieties, Harmé Naska and Harmé Lasoore. For collecting the local pear varieties, Mawet and Sitak in Sulaymaniyah-Iraq were visited during 2015. Selected pear trees were 15-18 years aged. From Mawet the local pear variety named Harmé Naska, and from Sitak the local pear variety, Harmé Lasoore, were collected, where both varieties were grafted on (Harmé Sheena) local pear trees. Fruits were picked on $15^{\text {th }}$ and $16^{\text {th }}$ October 2015. Fresh fruits without any deformation and injury were randomly selected for the study and transported to the laboratory at Kirkuk in net boxes. Fruits were selected randomly almost uniformed and not deformed, keeping in mind freshness, injure free, bearer kept on, then transported to Kirkuk in net boxes then wiped gently before refrigerating. Fruits were stored in laboratories of Agriculture College- Kirkuk University in two refrigerators, with the temperature of $5^{\circ} \mathrm{C}$ and $3{ }^{\circ} \mathrm{C}$ respectively. The refrigerators were loaded with pears for 30,60 and 90 days. Some pears were also kept on benches at ambient temperature. Depending on four sources of electric power to keep the refrigerators working 24 hrs a day. The following qualities that have been taken for the fruits: weight, total soluble solids and firmness.
\end{abstract}

\section{Article Info}

Accepted: 17 November 2016

Available Online: 06 December 2016

\section{Keywords}

Pear fruits

Pyrus communis

Qualitative characteristics

Storage

Temperature

\section{Introduction}

Pear (Pyrus communis L.) is native to coastal and temperate regions; it is one of the deciduous trees in the (Rosaceae) family, genus (Pyrus) which includes 24 species. It is original homeland is Western Europe and north of Iran crossing Asia from Caucasus to western north Himalaya Mountains Westwood (2002). In general, cultivation of pears succeeds in temperate areas between Latitude (33-60) north.
Commercial pear is confined to six main varieties: 'Bartlett,' 'Beurré d'Anjou,' 'Beurré Bosc,' 'Beurré Hardy,' 'Doyenne' du Comice,' and 'Seckel.' Other minor varieties include 'Winter Nelis,' 'El Dorado,' 'Kieffer,' and 'Packham's Triumph and important pear varieties grown in the United States belong to the European species (Skene, 1966). World rate of pear production in 2012 was about 23,580,845 metric tons; China comes in first place in with $17,325,831$ metric tons, followed by the US about 783,815 M.T. Then 
Argentina about 773,719 M.T. then Italy about 694,284 M.T. then Turkey 461,826 M.T. And other countries prod 3,541,370 metric tons (UN Food \& Agriculture Organization, 2012).

In addition to consumption of pear as a fresh fruit, it is used in many food industries as dried and canned fruits, juices, alcoholic drinks, jam, and as pectin sours, and it also enters in aromatic materials and detergents production. Maturity and harvesting dates of Pears in provinces of Kurdistan - Iraq varies depending on the cultivated varieties and environmental conditions and storage terms. The importance of pear comes from its high nutritional specifications. In addition to $83.71 \%$ water $100 \mathrm{~g}$ pear, Table 1 shows the rest complements:

Table 1. Pears contents. USDA Nutrient Database (2012).

\begin{tabular}{ll}
\hline Energy & $(57 \mathrm{kcal})$ \\
Carbohydrates: & $15.23 \mathrm{~g}$ \\
Sugars & $9.75 \mathrm{~g}$ \\
Dietary fiber & $3.1 \mathrm{~g}$ \\
Fat & $0.14 \mathrm{~g}$ \\
Protein & $0.36 \mathrm{~g}$ \\
Vitamins: Thiamine (B1) & $0.012 \mathrm{mg}$ \\
Riboflavin (B2) & $0.026 \mathrm{mg}$ \\
Niacin (B3) & $0.161 \mathrm{mg}$ \\
Pantothenic acid (B5) & $0.049 \mathrm{mg}$ \\
Vitamin B6 & $0.029 \mathrm{mg}$ \\
Folate (B9) & $7 \mu \mathrm{g}$ \\
Choline & $5.1 \mathrm{mg}$ \\
Vitamin C & $4.3 \mathrm{mg}$ \\
Vitamin E & $0.12 \mathrm{mg}$ \\
Vitamin K & $4.4 \mu \mathrm{g}$ \\
Minerals: Calcium & $9 \mathrm{mg}$ \\
Iron & $0.18 \mathrm{mg}$ \\
Magnesium & $7 \mathrm{mg}$ \\
Manganese & $0.048 \mathrm{mg}$ \\
Phosphorus & $12 \mathrm{mg}$ \\
Potassium & $116 \mathrm{mg}$ \\
Sodium & $1 \mathrm{mg}$ \\
Zinc & $0.1 \mathrm{mg}$ \\
\hline
\end{tabular}

\section{Materials and methods}

Field works: This work started in 2015 with field work to collect pears, for that purpose a visit to Mawet, $55 \mathrm{~km}$ north of Sulaymaniyah was done, another visit done to Sitak, $20 \mathrm{~km}$ eastern-north of Sulaymaniyah, both have a cold winter and a moderate summer, mountainous topography. Selected pear trees were 15-18 years aged as gardeners told us. Mawet has the local pear variety named (Harmé Naska), and Sitak has the local variety (Harmé Lasoore), where both varieties were grafted on (Harmé Sheena) local pear trees. Picking fruits was carried and on 10/15/2015 and 10/16/2015. Fruits were selected randomly almost uniformed and not deformed, keeping in mind freshness, injure free, bearer kept on, then transported to Kirkuk in net boxes then wiped gently before refrigerating.

Storage operations: Storage has been in laboratories of Agriculture College- Kirkuk University, a week before putting the fruits in the refrigerators, two refrigerators were washed with detergent and sterilized by ethanol and acetone. Then they were started to reach the desired temperate. One of them was set on $5 \mathrm{C}^{\circ}$, the other one on $3 \mathrm{C}^{\circ}$. Loaded with pears for $(30,60,90)$ days. Keeping some pears on benches at the lab. Ambient temperature. Depending on four sources of electric power to keep the refrigerators working $24 \mathrm{hrs}$ a day.

\section{Laboratory studies}

1. Fruit weight (g): The fruits every single weight separately using a sensitive balance.

2. Total Soluble Solids (\%): Measured by using Refracto meter device.

3. Firmness $\left(\mathbf{k g} / \mathbf{c m}^{2}\right)$ : Measured by using a special device fruit hardness tester model CY-3 measuring fruits such as apples and pears.

The analysis was done by using factorial experiments split plot design Completely Randomized Block Design (CRBD), with three factors and three replicates, and uses Duncan's Multiple Range 0.05 to compare between means of the experiment treatments, the first factor which temperatures Storage (3) and (5) and the degree of laboratory, and the second factor is the two local varieties of pears, and the third factor is the duration of storage $(30,60,90)$ Day with three replications and (5) fruits for each treatments where temperatures are the (main) factor and varieties are secondary factor (split) and the duration of storage (sub split) using readystatistical program, The Statistical Analysis System (SAS, 2001).

\section{Results and discussion}

Table 2 represents fruits weight, which shows no significant deference in the weight of the fruits stored at $3^{\circ} \mathrm{C}(\mathrm{C} 1), 5^{\circ} \mathrm{C}$ (C2) and room temperature (C3) in the end of the storage period. Also there was no significant deference among the second factor the two varieties (V) Harmé Lasoore (V1) and Harmé Naska (V2), the 3rd factor (T) storage period for 
30(T1), 60(T2), 90(T3) days also gave no significant deference, neither the interaction between $\mathrm{C}$ and $\mathrm{V}(\mathrm{C} \times \mathrm{V})$ gave a significant deference. As well as $(\mathrm{C} \times \mathrm{T})$. As well as $(\mathrm{V} \times \mathrm{T})$. But the interaction between the three factors $(\mathrm{C} \times \mathrm{V} \times \mathrm{T})$ showed a significant deference on $\mathrm{C} 1 \mathrm{~V} 2 \mathrm{~T} 2$, where gave the highest weight 72.45 .

A comparison between Table 2 with Table 3 in addendum which represents weight change in fruits before and after storage shows change agrees with the explanation by Hayat et al. (2003), Meberg et al. (2000) and Crisosto et al. (1994), which states that the thickness of cuticle layer and waxy materials covering the fruits acts on transpiration and evaporation's speed. That is why pear loses weight more than apple under the same storing condition because waxy layer is thicker on apple than on pear. Also weight and size loss may be caused by disintegration of pectin and waxy layer covering peel and increases respiration and moisture loss then redaction of fruit's weight (Gorrini and Sozzi, 1981).

Table 2. Effect and interactions of storage temperature, storage period, and varieties on fruits weight (g) after storage

\begin{tabular}{|c|c|c|c|c|c|}
\hline \multirow{2}{*}{ Variety $(\mathbf{V})$} & \multirow{2}{*}{ Treatment $(\mathbf{T})$} & \multicolumn{3}{|c|}{ Storage temperature $(\mathrm{C})$} & \multirow{2}{*}{$\mathbf{V} \times \mathbf{T}$} \\
\hline & & $\mathrm{C1}$ & $\mathrm{C} 2$ & C3 & \\
\hline \multirow[t]{3}{*}{ V1 } & T1 & $44.04 \mathrm{~b}$ & $57.41 \mathrm{~b}$ & $53.43 \mathrm{~b}$ & $51.61 \mathrm{a}$ \\
\hline & $\mathrm{T} 2$ & $62.87 \mathrm{~b}$ & $42.54 \mathrm{~b}$ & $51.01 \mathrm{~b}$ & $52.15 \mathrm{a}$ \\
\hline & T3 & $40.16 \mathrm{~b}$ & $41.35 \mathrm{~b}$ & $39.85 \mathrm{~b}$ & $40.42 \mathrm{a}$ \\
\hline \multirow[t]{3}{*}{ V2 } & T1 & $61.27 \mathrm{~b}$ & $36.53 \mathrm{~b}$ & $39.45 \mathrm{~b}$ & $45.71 \mathrm{a}$ \\
\hline & $\mathrm{T} 2$ & $72.45 \mathrm{a}$ & $58.28 \mathrm{~b}$ & $35.92 \mathrm{~b}$ & $55.53 \mathrm{a}$ \\
\hline & T3 & $52.95 \mathrm{~b}$ & $45.31 \mathrm{~b}$ & $34.90 \mathrm{~b}$ & $\begin{array}{l}44.37 \mathrm{a} \\
\mathbf{V}\end{array}$ \\
\hline \multirow[t]{2}{*}{$\mathbf{C} \times \mathbf{V}$} & V1 & $49.04 \mathrm{a}$ & $47.15 \mathrm{a}$ & $48.18 \mathrm{a}$ & $48.01 \mathrm{a}$ \\
\hline & V2 & $49.09 \mathrm{a}$ & $46.73 \mathrm{a}$ & $36.76 \mathrm{a}$ & $\begin{array}{l}44.19 \mathrm{a} \\
\mathbf{T}\end{array}$ \\
\hline \multirow[t]{3}{*}{$\mathbf{C} \times \mathbf{T}$} & $\mathrm{T} 1$ & $52.62 \mathrm{a}$ & $47.00 \mathrm{a}$ & $46.47 \mathrm{a}$ & $48.72 \mathrm{a}$ \\
\hline & $\mathrm{T} 2$ & $51.46 \mathrm{a}$ & $50.40 \mathrm{a}$ & $43.51 \mathrm{a}$ & $49.54 \mathrm{a}$ \\
\hline & T3 & $46.57 \mathrm{a}$ & $43.33 \mathrm{a}$ & $37.36 \mathrm{a}$ & $42.43 \mathrm{a}$ \\
\hline C & & $50.12 \mathrm{a}$ & $46.90 \mathrm{a}$ & $42.40 \mathrm{a}$ & \\
\hline
\end{tabular}

Mean values with different superscripts within a column differ significantly $(p \leq 0.05)$.

Table 3. Traits of research before storage operation for 18 diacritics.

\begin{tabular}{|c|c|c|c|}
\hline Diacritics & Weight (g) & TSS (Brix\%) & Hardness $\left(\mathrm{kg} / \mathrm{cm}^{2}\right)$ \\
\hline 1 & 47.71 & 10 & 11 \\
\hline 2 & 58.72 & 10.66 & 12 \\
\hline 3 & 52.22 & 11 & 10.26 \\
\hline 4 & 72.77 & 17.33 & 11.61 \\
\hline 5 & 55.06 & 17 & 11.92 \\
\hline 6 & 65.08 & 17.33 & 11.66 \\
\hline 7 & 61.69 & 12 & 10.23 \\
\hline 8 & 48.48 & 13.33 & 9.96 \\
\hline 9 & 51.26 & 11 & 10.13 \\
\hline 10 & 55.15 & 16 & 11.76 \\
\hline 11 & 41.01 & 17 & 11.16 \\
\hline 12 & 69.13 & 16.66 & 9.66 \\
\hline 13 & 61.54 & 10.66 & 8.5 \\
\hline 14 & 61.2 & 15 & 9.46 \\
\hline 15 & 54.7 & 13.66 & 9.13 \\
\hline 16 & 53.95 & 15 & 11.43 \\
\hline 17 & 60.55 & 15 & 11 \\
\hline 18 & 54.88 & 14.64 & 11.43 \\
\hline
\end{tabular}

Table 4, which represents fruits firmness, significant deference among first factor, where highest number of 10.53 was observed at $\mathrm{C} 2$, and gave least number of 0.79 at $\mathrm{C} 3$; there was a significant deference among the second factor $(\mathrm{V})$ where the highest number of 7.83 was observed in (V2) and the least number of 6.12 was observed in (V1); There was no significant difference among the third factor $(\mathrm{T})$. 
Showing at interaction between $(\mathrm{C} \times \mathrm{V})$, gave a significant difference, where the highest number observed was 11.27 and 10.07 at $\mathrm{C} 1 \times \mathrm{V} 2, \mathrm{C} 2 \times \mathrm{V} 2$ in sequence. As well as $(\mathrm{C} \times \mathrm{T})$, where the highest number was 10.23 at $\mathrm{C} 2 \times \mathrm{T} 2$, and gave least number of 0.58 and 0.33 at $\mathrm{C} 3 \times \mathrm{T} 2$ and $\mathrm{C} 3 \times \mathrm{T} 3$. As well as $(\mathrm{V} \times \mathrm{T})$, where the highest number was
7.46 at $\mathrm{V} 2 \times \mathrm{T} 1$, and other interaction gave least numbers. The interaction between the three factors $(\mathrm{C} \times \mathrm{V} \times \mathrm{T})$ showed a significant difference where the highest fruit firmness was 10.56 at $\mathrm{C} 1 \times \mathrm{V} 2 \times \mathrm{T} 1,10.33$ at $\mathrm{C} 1 \times \mathrm{V} 2 \times \mathrm{T} 2$, 10.35 at $\mathrm{C} 1 \times \mathrm{V} 2 \times \mathrm{T} 3,10.32$ at $\mathrm{C} 2 \times \mathrm{V} 2 \times \mathrm{T} 1,10.04$ at $\mathrm{C} 2 \times \mathrm{V} 2 \times \mathrm{T} 2$, and gave least 0.00 at $\mathrm{C} 3 \times \mathrm{V} 2 \times \mathrm{T} 3$.

Table 4. Effect and interactions of storage temperature, storage period, and varieties on fruits hardness $\left(\mathrm{kg} / \mathrm{cm}^{2}\right)$ after storage.

\begin{tabular}{|c|c|c|c|c|c|}
\hline \multirow{2}{*}{ Variety $(\mathbf{V})$} & \multirow{2}{*}{ Treatment (T) } & \multicolumn{3}{|c|}{ Storage temperature $(\mathrm{C})$} & \multirow{2}{*}{$\mathbf{V} \times \mathbf{T}$} \\
\hline & & C1 & $\mathrm{C2}$ & C3 & \\
\hline \multirow[t]{3}{*}{ V1 } & $\mathrm{T} 1$ & $9.06 \mathrm{~b}$ & $8.93 \mathrm{~b}$ & $1.43 \mathrm{~d}$ & $6.47 \mathrm{~b}$ \\
\hline & $\mathrm{T} 2$ & $7.66 \mathrm{c}$ & $9.56 \mathrm{~b}$ & $1.00 \mathrm{de}$ & $6.07 \mathrm{~b}$ \\
\hline & T3 & $7.16 \mathrm{c}$ & $9.66 \mathrm{~b}$ & $0.66 \mathrm{de}$ & $5.83 \mathrm{~b}$ \\
\hline \multirow[t]{3}{*}{$\mathbf{V} 2$} & $\mathrm{~T} 1$ & $10.56 \mathrm{a}$ & $10.32 \mathrm{a}$ & $1.50 \mathrm{~d}$ & $7.46 \mathrm{a}$ \\
\hline & $\mathrm{T} 2$ & $10.33 \mathrm{a}$ & $10.04 \mathrm{a}$ & $0.16 \mathrm{de}$ & $6.84 \mathrm{~b}$ \\
\hline & $\mathrm{T} 3$ & $10.35 \mathrm{a}$ & $8.34 \mathrm{~b}$ & $0.00 \mathrm{e}$ & $\begin{array}{l}6.23 \mathrm{~b} \\
\mathrm{~V}\end{array}$ \\
\hline \multirow[t]{2}{*}{$\mathbf{C} \times \mathbf{V}$} & V1 & $7.96 \mathrm{c}$ & $9.38 \mathrm{~b}$ & $1.03 \mathrm{~d}$ & $6.12 \mathrm{~b}$ \\
\hline & $\mathrm{V} 2$ & $11.27 \mathrm{a}$ & $10.07 \mathrm{a}$ & $0.55 \mathrm{~d}$ & $\begin{array}{l}7.83 \mathrm{a} \\
\mathbf{T}\end{array}$ \\
\hline \multirow[t]{3}{*}{$\mathbf{C} \times \mathbf{T}$} & $\mathrm{T} 1$ & $10.20 \mathrm{ab}$ & $10.15 \mathrm{ab}$ & $1.46 \mathrm{c}$ & $7.27 \mathrm{a}$ \\
\hline & $\mathrm{T} 2$ & $9.33 \mathrm{~b}$ & $10.23 \mathrm{a}$ & $0.58 \mathrm{~d}$ & $6.84 \mathrm{a}$ \\
\hline & T3 & $9.33 \mathrm{~b}$ & $9.11 \mathrm{~b}$ & $0.33 \mathrm{~d}$ & $6.83 \mathrm{a}$ \\
\hline C & & $9.62 \mathrm{~b}$ & $10.53 \mathrm{a}$ & $0.79 \mathrm{c}$ & \\
\hline
\end{tabular}

Mean values with different superscripts within a column differ significantly $(p \leq 0.05)$.

Table 5. Effect and interactions of storage temperature, storage period, and varieties on fruits TSS (Brix) after storage.

\begin{tabular}{|c|c|c|c|c|c|}
\hline \multirow{2}{*}{ Variety $(V)$} & \multirow{2}{*}{ Treatment $(\mathbf{T})$} & \multicolumn{3}{|c|}{ Storage temperature (C) } & \multirow{2}{*}{$\mathbf{V} \times \mathbf{T}$} \\
\hline & & C1 & C2 & C3 & \\
\hline \multirow[t]{3}{*}{ V1 } & T1 & $12.00 \mathrm{bcd}$ & $13.33 \mathrm{~b}$ & $10.66 \mathrm{~cd}$ & $12.00 \mathrm{~b}$ \\
\hline & $\mathrm{T} 2$ & $10.66 \mathrm{~cd}$ & $12.66 \mathrm{bc}$ & $11.00 \mathrm{~cd}$ & $11.44 \mathrm{~b}$ \\
\hline & T3 & $10.00 \mathrm{~d}$ & $10.33 \mathrm{~cd}$ & $13.33 \mathrm{~b}$ & $11.22 \mathrm{~b}$ \\
\hline \multirow[t]{3}{*}{ V2 } & $\mathrm{T} 1$ & $16.33 \mathrm{a}$ & $16.66 \mathrm{a}$ & $17.00 \mathrm{a}$ & $16.66 \mathrm{a}$ \\
\hline & $\mathrm{T} 2$ & $17.66 \mathrm{a}$ & $17.66 \mathrm{a}$ & $17.00 \mathrm{a}$ & $17.44 \mathrm{a}$ \\
\hline & $\mathrm{T} 3$ & $15.66 \mathrm{a}$ & $17.00 \mathrm{a}$ & $18.00 \mathrm{a}$ & $\begin{array}{l}16.88 \mathrm{a} \\
\mathbf{V}\end{array}$ \\
\hline \multirow[t]{2}{*}{$\mathbf{C} \times \mathbf{V}$} & V1 & $10.88 \mathrm{~b}$ & $12.11 \mathrm{~b}$ & $11.66 \mathrm{~b}$ & $11.55 \mathrm{~b}$ \\
\hline & V2 & $16.55 \mathrm{a}$ & $17.11 \mathrm{a}$ & $17.33 \mathrm{a}$ & $\begin{array}{l}17.00 \mathrm{a} \\
\mathbf{T}\end{array}$ \\
\hline \multirow[t]{3}{*}{$\mathbf{C} \times \mathbf{T}$} & $\mathrm{T} 1$ & $14.16 \mathrm{abc}$ & $15.00 \mathrm{ab}$ & $13.83 \mathrm{bc}$ & $14.33 \mathrm{a}$ \\
\hline & $\mathrm{T} 2$ & $14.16 \mathrm{abc}$ & $15.16 \mathrm{ab}$ & $14.00 \mathrm{bc}$ & $14.44 \mathrm{a}$ \\
\hline & T3 & $12.83 \mathrm{c}$ & $13.66 \mathrm{bc}$ & $15.66 \mathrm{a}$ & $14.05 \mathrm{a}$ \\
\hline C & & $13.72 \mathrm{a}$ & $14.61 \mathrm{a}$ & $14.50 \mathrm{a}$ & \\
\hline
\end{tabular}

Mean values with different superscripts within a column differ significantly $(p \leq 0.05)$.

A comparison between Table 4 with Table 3, represents the firmness change in fruits before and after storage, declination of all the three characteristics after storage shows reducing fruit after than before storage that's agrees with consistent Firmness values for Jonagold and Golden Delicious apples were strongly influenced by storage atmosphere at 30 days after harvest. A firmness loss of $15.2 \%$ and $9.3 \%$ was determined for Jonagold and
Golden Delicious, respectively, for those apples stored 30 days compared with identical apples from 30 days (Meheriuk, 1984).

Table 5 represents fruits total soluble solids (TSS) after storage, shows no significant deference among first factor (C), there was significant deference among the second factor $(\mathrm{V})$, where the highest number was 
observed 17.00 at V2, and the least mean of TSS 11.55 was observed at V1 and there was no significant difference among the third factor $(\mathrm{T})$.

Showing at interaction between $(\mathrm{C} \times \mathrm{V})$ gave a significant difference, all interactions of V2 gave highest number, and gave least numbers in V1. As well as $(\mathrm{C} \times \mathrm{T})$ gave the highest number of 15.66 at $\mathrm{C} 3 \times \mathrm{T} 3$, and least number 12.83 at $\mathrm{C} 1 \times \mathrm{T} 3$. Also $(\mathrm{V} \times \mathrm{T})$ gave the highest means of TSS in V2 for all storage periods, and gave least means in V1 for all storage period. The interaction between the three factors $(\mathrm{C} \times \mathrm{V} \times \mathrm{T})$ showed a significant difference where the highest fruit total soluble solids (TSS) was observed in V2 for all storage temperature and period, and the least was 10.00 at $\mathrm{C} 1 \times \mathrm{V} 1 \times \mathrm{T} 3$.

A comparison between Table 5 with Table 3, represents the total soluble solids (TSS) change in fruits before and after storage, all the three characteristics after storage shows change total soluble solids (TSS) in fruit after than before storage that agrees with a study of storing six varieties, 'Alexander Lukas', 'Amfora', 'Delbuena', 'Delmoip', 'Erica', and 'Nojabrska', of pears which showed that there was also a slight, but statistically insignificant increase in TSS during controlled atmosphere storage both in 2003/2004 and 2004/2005. This increase may be due to starch degradation, especially in 'Delbuena', which had a starch index of 1 at harvest time. The only cultivar to show a slight, but statistically insignificant decrease in TSS content was 'Nojabrska', which had a starch index of 10 at harvest time. It is difficult to predict the TSS content after the storage period because it also depends on transpiration and respiration, which use carbohydrates as a source of energy, as well as study, though, TSS content increased slightly after eight months of storage Wawrzyńczak et al. (2006), Chen and Mellenthin (1982).

\section{Conflict of interest statement}

Authors declare that they have no conflict of interest.

\section{References}

Wawrzyńczak, A., Rutkowski, K. P., Kruczyńska, D. E., 2006. Changes in fruit quality in pears during CA storage. J. Fruits Ornam. Plant Res. 14(Suppl.2), 77-84.

Chen, P.M., Mellenthin, W.M., 1982. Storage behavior of 'd'Anjou' pears in low oxygen and air. In: Controlled Atmosphere for Storage and Transport of Perishable Agricultural Commodities (Eds.: Richardson, D.G., Meheriuk, M.). Timber Press, Beaverton, OR, USA. pp.139-148.

Crisosto, C.H.,Garner, D., Crisosto, G.M., Sibbett, G.S., Day, K.R., 1994. Late harvest and delayed cooling induce internal browning of 'Yali' and 'Seuri' Chinese pears. HortSci. 29(6), 667-670.

Gorrini, F.L., Sozzi, A., 1981. Weight losses stored of apples can be contained. Informator Agrario. 37(7), $14087-$ 14088.

Hayat, I. Masud, T., Rathore, H.A., 2003. Effect of coating and wrapping materials on the shelf life of apple (Malus domestica acv. Borkh). Internet J. Food Saf. V(5), 24-34.

Meberg, K.R., Haffner, K., Rosenfeld, H.J., 2000. Storage and shelf-life of Norwegian grown apple: I. The effect of controlled atmosphere storage on 'Aroma'. Gartenbauwissenschaft. 65(1) 9-16.

Meheriuk, M., Lau, O.L., Hall, J.W., 1984. Effect of some postharvest storage treatments in the incidences of flesh browning in controlled atmosphere stored delicious apples. J. Amer. Soc. Hort. Sci. 109, 290-293.

Skene, D.S., 1966. The distribution of growth and cell division in the fruit of Cox's Orange Pippin. Ann. Bot. 30, 493512.

UN Food \& Agriculture Organization, 2012. Production of Pears by Countries and World Total, Statistics Division.

USDA Nutrient Database for pears contained in 2012.

Westwood, M. N.,2002.Personal Communication. Corvallis: Oregon State University.

\section{How to cite this article:}

Ismail Ahmed, A., Mohamad Khalaf, J., Saeed Amin, S., 2016. Effect of temperature and duration of storage on some qualitative characteristics of two local varieties of pear fruits (Pyrus communis). Int. J. Curr. Res. Biosci. Plant Biol. 3(12), 44-48. doi: http://dx.doi.org/10.20546/ijcrbp.2016.312.006 